\title{
SEPARATION OF MINERAL MATTER FROM INDIAN COAL BY USING SOLVENTS
}

\author{
Rajat Subhra Samanta ${ }^{1}$, Chanchal Mondal ${ }^{2}$ \\ ${ }^{1}$ Master of Chemical Engineering Department, Jadavpur University, Kolkata, India \\ ${ }^{2}$ Associate Professor, Chemical Engineering Department, Jadavpur University, Kolkata, India
}

\begin{abstract}
Coal resources have been estimated at over 861 billion tone globally. India accounts for 236 billion tonne of coal. Coal meets around $30.3 \%$ of global primary energy needs and generates $42 \%$ of the world's electricity. Indian electricity capacity has a rapid growth from 1350MW in the year 1947 to more than 140,000MW presently. Wide spectrum of coal is required ranging from power generation to steel production, infrastructure and commercial purposes. Indian coals contain high in ash content ranging from 15\% to 55\% [1] but low in sulphur content. Power plants complain of high ash content, inconsistent quality and size. Research and process development to produce the ash-free coal (Hyper-coal, HPC) has been carrying out since 1999 [5]. To improve the quality of coal by washing to reduce the environmental impact, enhance coal quality and increase process efficiency. Coal washing and coal beneficiation processes are the major thrust in terms of developing strong research cells for developing better practices, suiting requirements of all the coalfields of India. The extraction yield depends strongly on the coal particle size, solvent and extraction conditions. Experimental investigation for removal of mineral matter from Indian coal by using three different solvents such as Tetrahydrofuran, 1,4 Dioxane and Diethyl ether. Comparative study on reduction of ash content of Indian coals having different average particle sizes $(0.126 \mathrm{~mm}, 0.258 \mathrm{~mm}$ and $0.403 \mathrm{~mm})$ using different solvents reveals that Tetrahydrofuran is the best solvent with respect to these used solvents. The maximum reduction of ash content is found to be $23.16 \%$. Experimental studies also highlighted how ash removal of coal by using solvents is increased with the decrease of particle size due to the easy liberation of ash bearing components from coal particles [16].
\end{abstract}

Keywords: Ash-free coal, Coal particle size, Coal beneficiation, Tetrahydrofuran, 1, 4 Dioxane, Diethyl ether

\section{INTRODUCTION}

Coal is found throughout the world and is expected to play a critical role as an abundant primary energy source in the $20^{\text {th }}$ centure. However, one critical issue in promoting coal utilizes in an environmental acceptability and improves coal utilization efficiency. The utilization of coal in various coal conversion processes like combustion, liquefaction and pyrolysis. The coal has several positive attributes considered as a feedstock for aromatic chemicals and carbon based materials [28].

The proposed demand of coal during 2016-17 mainly include electricity, iron, steel and cement as per India Energy Book 2012 is shown in figure 1 and estimated coal consumption sector - wise in India proposed by Indian Energy Book during 2031-32 is shown in figure 2.

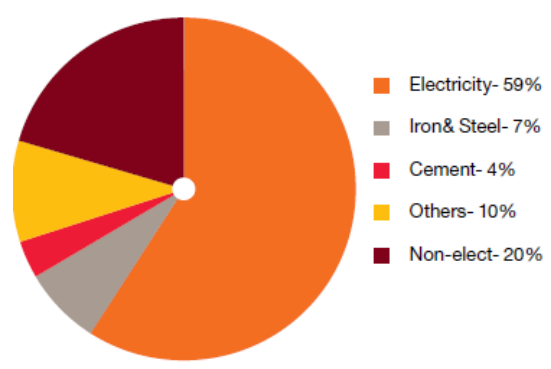

Fig 1-: Estimated sector-wise coal consumption in India (2016-17)

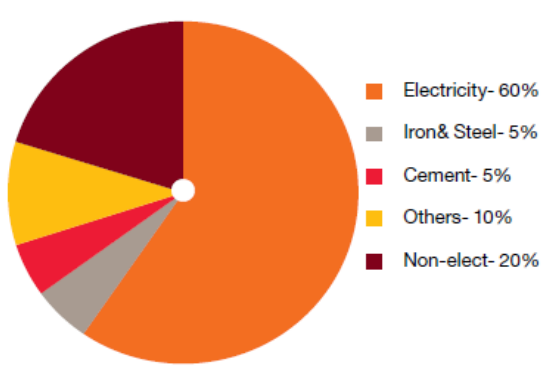

Fig 1-: Estimated sector-wise coal consumption in India(2031-32) 
Most of the problems associated with coal utilization arise in some way from the mineral matter (Gupta et al 1996). The most common mineral matters in coal are various forms of silica like quartz, opal, cherts etc and clay minerals. The presence of mineral matter adversely affects most aspects of coal utilization and processing. Minerals in coal are troublesome materials in the combustors by forming the ash during coal combustions. In addition, ash disposal is also becoming a large problem because the ash disposal site will be filled up near the future [5]. Both physical and chemical methods are envisages to remove the mineral matter from coal. The processes of removal of mineral matter from coal by conventional physical separation techniques such as washing and tabling have only a limited uses because extent of separation is very low. Hence, in this study chemical leaching is incorporated which involves treatment of coal with different chemicals reagents. Only the solubilized mineral matters present in coal could be effectively removed from mineral matters [8]. The removal of ash from high ash content Indian coal by chemical leaching methods can be produced in a reasonable price. Mineral-free coal could also be burned more efficiently and solve ash related problems. Coal is heterogeneous material which has a macromolecular structure consists of chain of aromatic and hydro-aromatic units which are joined together by covalent cross links, hydrogen bonds and van der waals interactions. The macromolecular structure has great importance for both solvent extraction at ambient temperature and pressure. According to Larsen, coal is covalently bonded network cluster (Larsen et al. 1985). The clusters are made up of fused aromatic rings to which various functional groups are attached. These clusters are held together by means of hydrogen bonding, aliphatic side chains ether linkage etc. A solvent can disrupt the internal interaction in network by replacing coal-coal bonds or hydrogen bonds with stronger coal solvent hydrogen bonds. The solvent properties such as solubility parameter, electron donar acceptor number (EDN-EAN) key parameters for extraction.
The electron donor acceptor (e-d-a) bonds are responsible for binding together the coal macromolecular network and extractable substances.

Demineralization of coal depends on reaction time, temperature, coal-solvent ratio, particle size and also nature of coal sample. Literatures show that the ash content of coal, measured by the ASTM standard, depends on particle size [910] and some studies also show [11-14] that particle size also has a significant influence on the extraction process for demineralization of coal. The influence of reagents on the coal for demineralization and the extent of dissolution of coal in matrix form are highly important [15]. In this paper effects of solvents as well as effect of particle sizes on reduction of mineral matter from have been broadly studied. Since finer fraction of coal increases the surface area exposed to the reagents as a result more minerals matters of finer coal fractions scattered through the coal carbonaceous matrix within exposed reagent which yields more soluble compounds.

\section{MATERIAL AND METHOD}

Coal samples have been collected from market having high percentages of ash. It has been crushed by using Jaw and Roll crusher. The crushed sample has been separated in three fractions by passed through Tyler Standard Mesh Sieves stacked vertically in descending order of mesh of $30,36,60,90,100$ and 200 respectively with a collector pan at the base and it have been sieved for 15 min using a vibratory shaker. The volume surface mean diameters (D) of the samples have been calculated by taking different fraction from different sieves. The volume surface mean diameter of the first is $0.126 \mathrm{~mm}$ and it has been leveled sample A. Similarly the volume surface mean diameter (D) of second cut is $0.258 \mathrm{~mm}$ have been leveled sample B. Final volume surface mean diameter of third cut is $0.403 \mathrm{~mm}$ has been leveled $\mathrm{C}$. The flow diagram of the process has been shown in figure 3 .

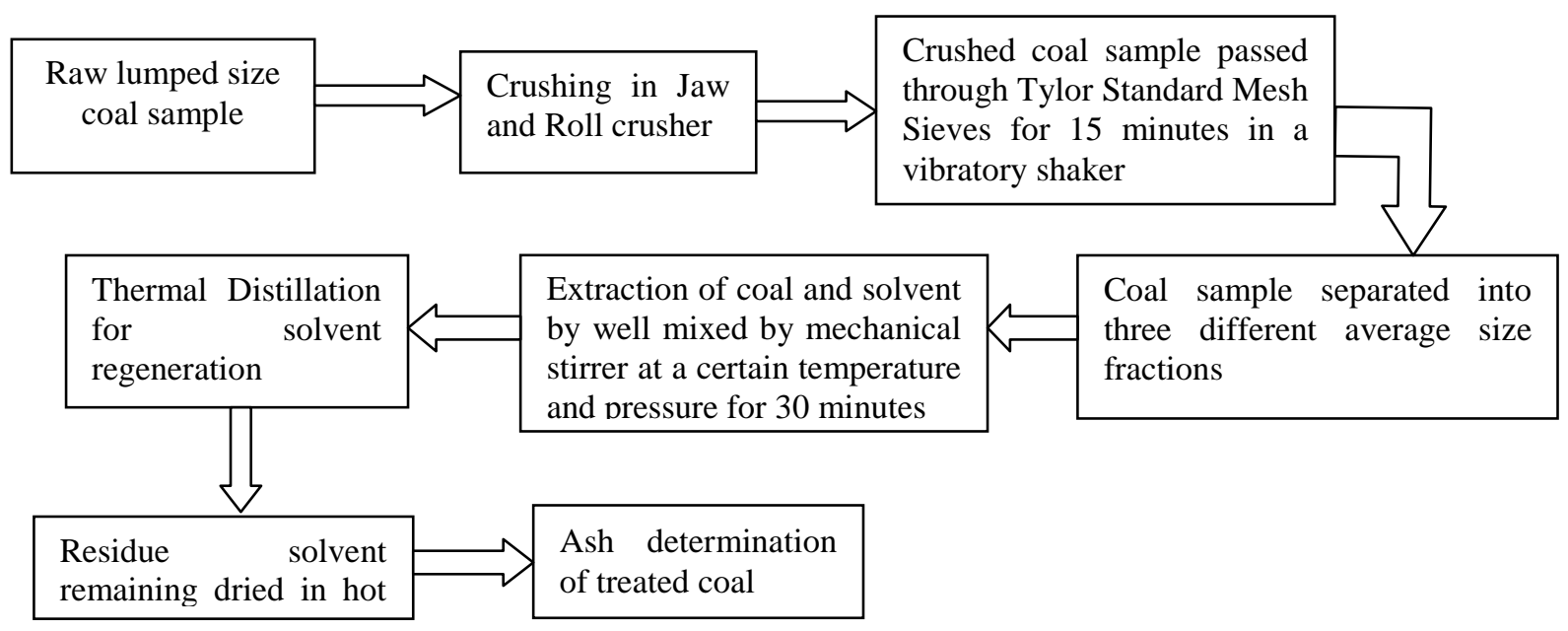

Fig 3-: Flow diagram of experimental process for demineralization of Indian coal 


\section{EXPERIMENTAL PROCEDURE}

\subsection{Coal Extraction}

$1 \mathrm{gm}$ of sample A has been taken in beaker. It has been well mixed by mechanical stirred at a speed of 980rpm and the solution is electrically heated by means of a controlled heating mantle. The extraction is carried out for half an hour under a specific temperature for a specific solvent as shown in figure 4. After extraction process the mixture of coal and solvent is placed in a thermal distillation column as shown in figure 5.
The system is kept under 1 atm pressure. After distillation process remaining solvent and coal have been heated in hot air oven to dry up sample. Ash content of treated coal sample has been determined by using proximate analysis. To enumerate the concentration effect on the extraction process for ash removal of a coal sample have been conducted at various coalsolvent ratio until ash removal becomes constant value at a certain coal-solvent ratio. Same procedure has been repeated for sample B and sample $\mathrm{C}$.

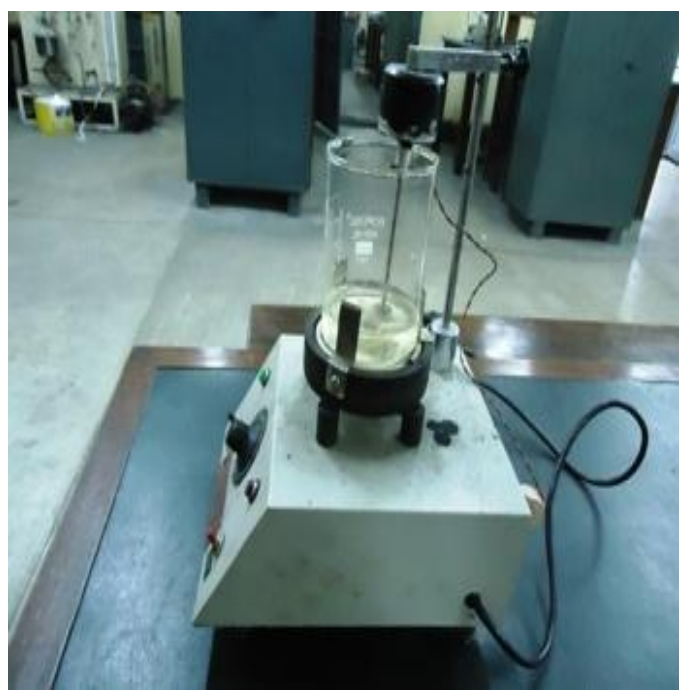

Fig 4:- Mechanical strirrer with continous heating system

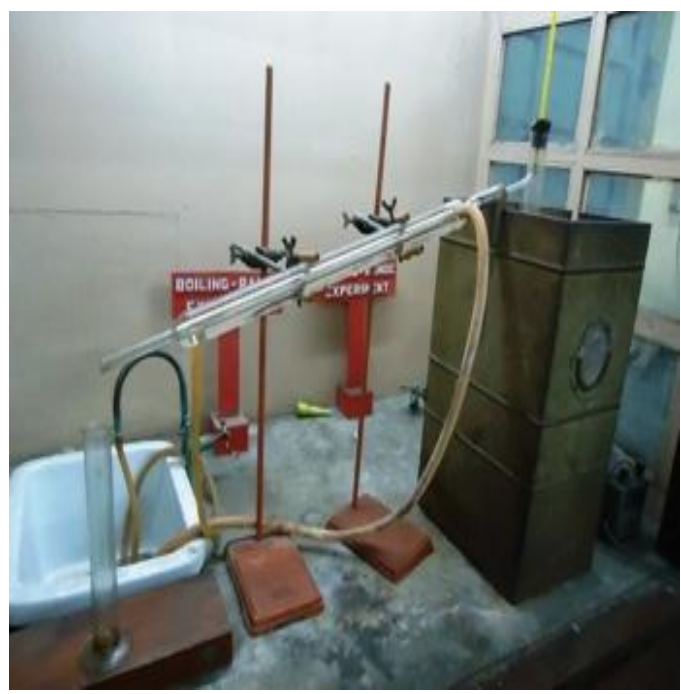

Fig 5:- Thermal Distillation column setup

\section{RESULTS AND DISCUSSION}

Many investigations have been conducted with respect to the reduction of ash of coal fractions leveled sample A, sample B and sample $\mathrm{C}$ having their different particle sizes. Three solvents have been used for ash reduction of coal of Sample A, Sample B and Sample C. Three solvents have been applied to separate ash content of coal of different samples having their different particle sizes and the performance of the solvents has been broadly discussed sample wise.

\subsection{Removal of Ash Content of Sample A}

The experimental results have been tabulated in table 1 and experimental data have been plotted in figure 6 . It has been observed from experimental result that separation of mineral matter of coal is possible from this coal sample using solvents Tetrahydrofuran, 1,4 Dioxane and Diethyl ether but the reduction of mineral matter of coal varies widely for different solvents. Observed values of separated mineral matter are $8.47 \%$ to $19.78 \%$ in case of Tetrahydrofuran with a coal solvent ratio from 1:10 to 1:40 where as separated mineral matter are in the range of $6.21 \%$ to $12.83 \%$ in case of 1,4 Dioxane and $5.83 \%$ to $10.95 \%$ in case of Diethyl Ether with the same variation of coal to solvent ratios. It has been evident from figure 6 that the increase coal-solvent ratio increases the percentage of ash removal up to a particular value of coalsolvent ratio. The values of maximum ash removal has been observed at a coal-solvent ratio of 1:60 are $23.16 \%, 15.26 \%$, $12.42 \%$ in case of Tetrahydrofuran, 1,4 Dioxane and Diethyl Ether respectively. Maximum separation of mineral mater is found to be $23.16 \%$ in case of Tetrahydrofuran. It is clear from the figure that ash removal rate in Tetrahydrofuran is sharp in comparison with other two solvents. On the other hand there are some fluctuations with respect to ash reduction in case of 1,4 Dioxane and Diethylether upto 1:30 coal-solvent ratio. After that, it is clear from the figure 6 the ash reduction is increased widely in case of 1,4 Dioxane with respect to Diethyl Ether. 
Table- 1: Performance of Tetrahydrofuran, 1,4 Dioxane, Diethyl ether solvents on removal of ash content of sample A

\begin{tabular}{|l|l|l|l|}
\hline Coal: Solvent & $\begin{array}{l}\text { Percentage of ash } \\
\text { removal } \\
\text { Tetrahydrofuran }\end{array}$ & $\begin{array}{l}\text { Percentage of ash } \\
\text { in } \\
\text { removal in } \\
\text { 1,4 Dioxane }\end{array}$ & $\begin{array}{l}\text { Percentage of ash } \\
\text { removal in } \\
\text { Diethyl ether }\end{array}$ \\
\hline $1: 10$ & 8.47 & 6.21 & 5.83 \\
\hline $1: 20$ & 12.78 & 8.78 & 9.18 \\
\hline $1: 30$ & 17.39 & 10.32 & 10.95 \\
\hline $1: 40$ & 19.78 & 12.83 & 12.10 \\
\hline $1: 50$ & 22.33 & 14.28 & 12.35 \\
\hline $1: 60$ & 23.16 & 15.26 & 12.42 \\
\hline $1: 70$ & 23.16 & 15.26 & 12.42 \\
\hline
\end{tabular}

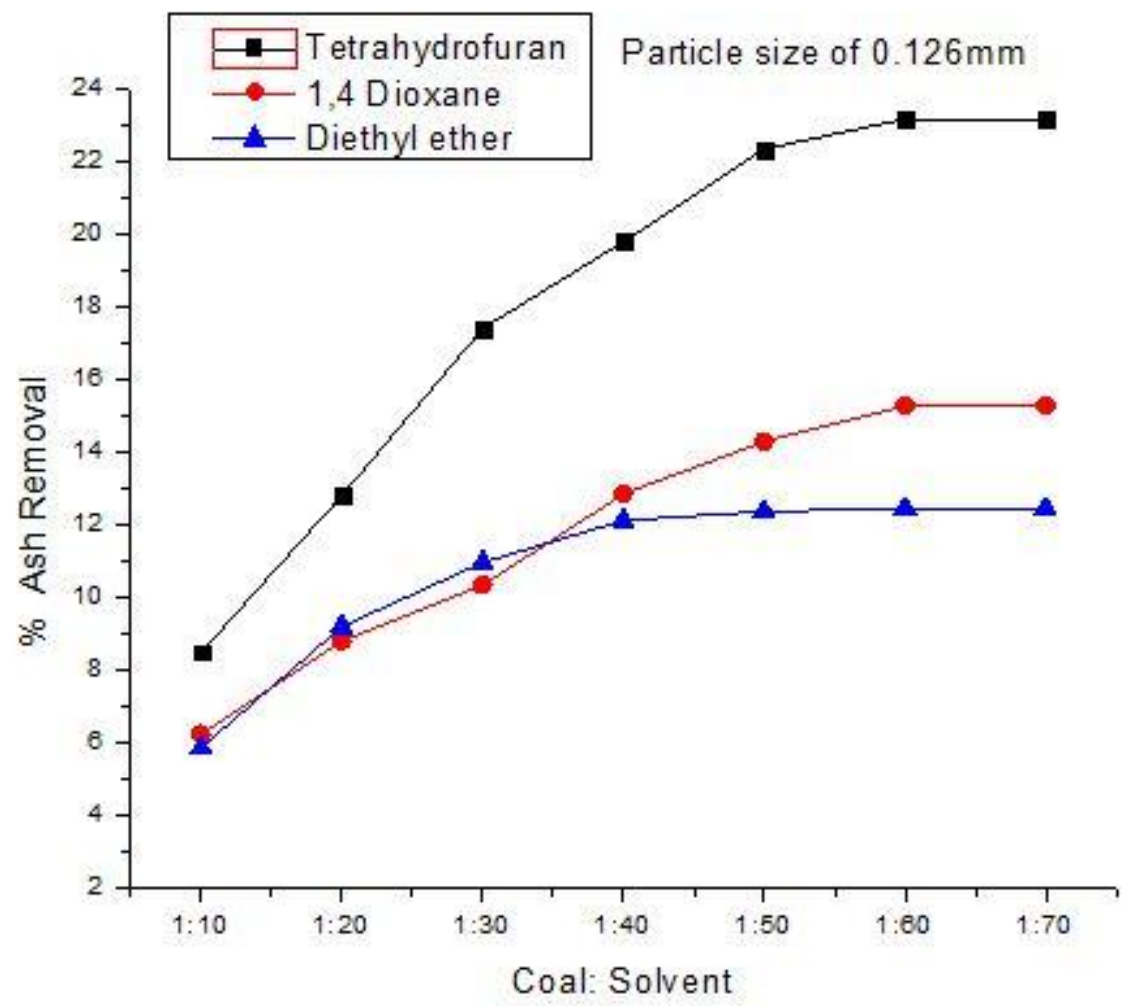

Fig 6:-Performance of Tetrahydrofuran, 1, 4 Dioxane, Diethyl ether solvents on removal of ash content of sample A

\subsection{Removal of Ash Content of Sample B}

The experimental results have been tabulated in table 2 and experimental data have been plotted in figure 7. Experimental result shows that with increase of coal-solvent ratio the ash removal from coal sample $\mathrm{B}$ in case of Tetrahydrofuran increases sharply with respect to other two solvents. It has been focused that ash reduction from sample B in case of Terahydrofuran with a solvent concentration $1: 10$ to $1: 50$ varies with a constant rate. But beyond these values the ash removal rate is reached to maximum and constant value making the similarities with sample A. Ash removal rate in case of Diethyl Ether is slightly higher than that of 1,4 Dioxane with 1:10 coal-solvent ratio. But at the coal-solvent ratio of 1:20 the ash removal rate in Diethyl ether is quite higher than that of 1,4 Dioxane.

Further increase of coal-solvent ratio up to $1: 30$ the ash removal rate in case of 1,4 Dioxane is slightly better than diethyl ether. But beyond this concentration $\%$ ash reduction in case of 1,4 Dioxane is higher and reached to a maximum value than that of diethyl Ether. 
Table 2: Performance of Tetrahydrofuran, 1,4 Dioxane, Diethyl ether solvents on removal of ash content of sample B

\begin{tabular}{|l|l|l|l|}
\hline Coal: Solvent & $\begin{array}{l}\text { Percentage of ash } \\
\text { removal } \\
\text { Tetrahydrofuran }\end{array}$ & $\begin{array}{l}\text { Percentage of ash } \\
\text { in }\end{array}$ & $\begin{array}{l}\text { Percentage of ash } \\
\text { removal in } \\
\text { 1,4 Dioxane } \\
\text { Diethyl ether }\end{array}$ \\
\hline $1: 10$ & 7.21 & 4.78 & 4.82 \\
\hline $1: 20$ & 11.74 & 6.83 & 8.36 \\
\hline $1: 30$ & 15.98 & 9.79 & 9.73 \\
\hline $1: 40$ & 20.56 & 11.58 & 10.53 \\
\hline $1: 50$ & 21.78 & 12.79 & 10.86 \\
\hline $1: 60$ & 21.78 & 13.91 & 10.86 \\
\hline $1: 70$ & 21.78 & 13.91 & 10.86 \\
\hline
\end{tabular}

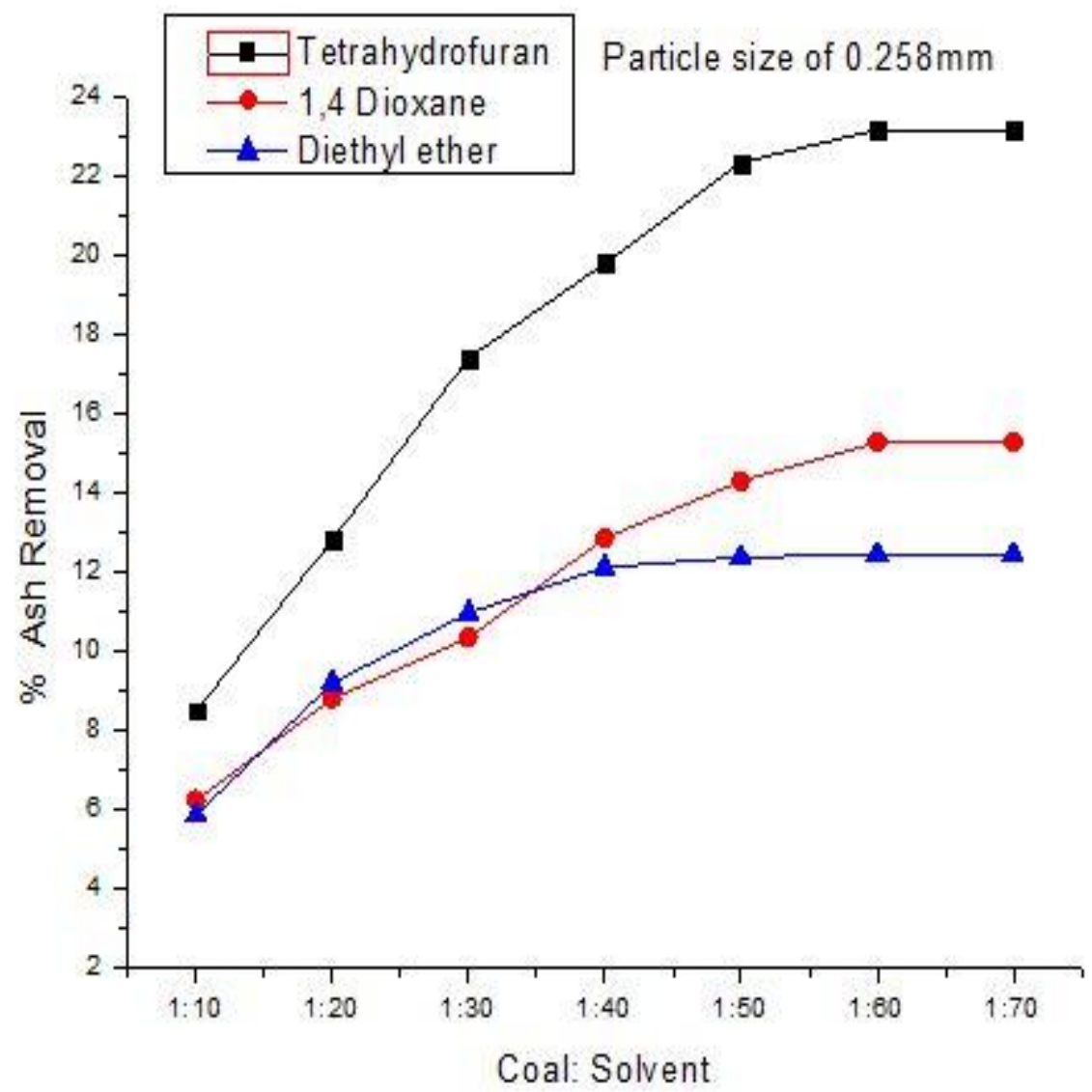

Fig 7:- Performance of Tetrahydrofuran, 1,4 Dioxane, Diethyl ether solvents on removal of ash content of sample B

\subsection{Removal of Ash Content of Sample C}

The experimental results have been tabulated in table 3 and experimental data have been plotted in figure 8 . It is clear from figure 8 that ash reduction of coal of sample $\mathrm{C}$ with a solvent concentration $1: 10$ to $1: 70$. But the reduction rate varies with type of solvents and also the concentration of solvents. The maximum reduction rate is obtained in case of Tetrahydrofuran $20.45 \%$. On the other hand initial reduction rate of ash content in case of Diethyl ether is little bit higher with respect to 1,4 Dioxane and shows the same reduction rate at a solvent concentration of near about 1:42. From the figure 8 it has been envisaged that from 1:10 to 1:40 coal-solvent ratio diethyl Ether has better percentage ash removal than 1,4 Dioxane. After which reduction rate is quite better in case of 1,4 Dioxane than that of Diethyl ether making the similarities with sample B. The maximum ash removals are found as per figure 8 to $11.52 \%$ and $9.76 \%$ in case of 1,4 Dioxane and Diethyl ether. 
Table 3: Performance of Tetrahydrofuran, 1,4 Dioxane, Diethyl ether solvents on removal of ash content of sample C

\begin{tabular}{|l|l|l|l|l|}
\hline Coal: Solvent & $\begin{array}{l}\text { Percentage of } \begin{array}{r}\text { ash } \\
\text { removal } \\
\text { Tetrahydrofuran }\end{array} \\
\text { in }\end{array}$ & $\begin{array}{l}\text { Percentage of ash } \\
\text { removal in } \\
1,4 \text { Dioxane }\end{array}$ & $\begin{array}{l}\text { Percentage of ash } \\
\text { removal in } \\
\text { Diethyl ether }\end{array}$ \\
\hline $1: 10$ & 5.96 & 3.53 & 3.87 \\
\hline $1: 20$ & 10.45 & 5.92 & 7.54 \\
\hline $1: 30$ & 14.69 & 7.84 & 8.68 \\
\hline $1: 40$ & 19.18 & 9.16 & 9.32 \\
\hline $1: 50$ & 20.45 & 10.84 & 9.53 \\
\hline $1: 60$ & 20.45 & 11.52 & 9.76 \\
\hline $1: 70$ & 20.45 & 11.52 & 9.76 \\
\hline
\end{tabular}

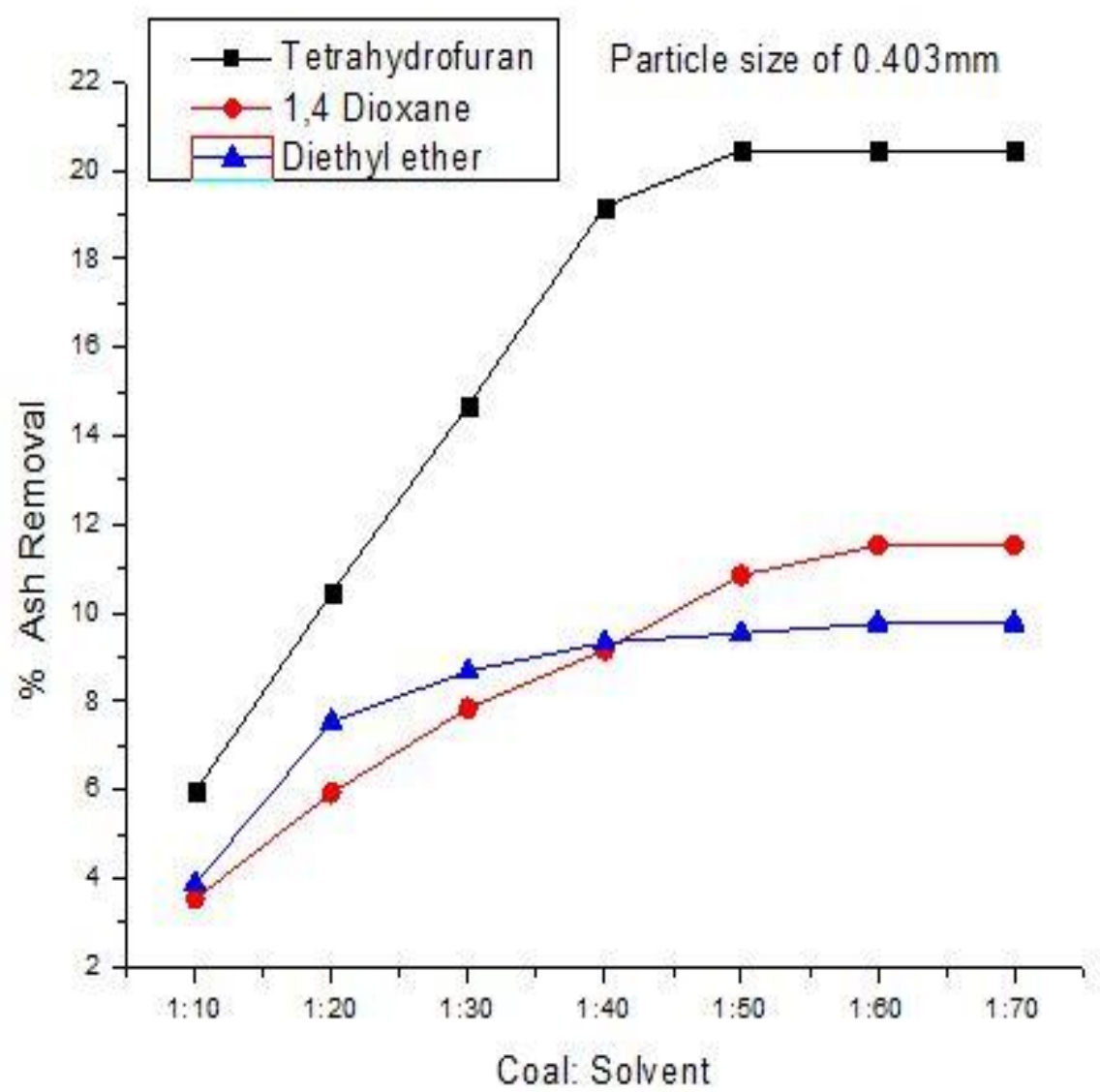

Fig 8:- Performance of Tetrahydrofuran, 1,4 Dioxane, Diethyl ether solvents on removal of ash content of sample C

\subsection{Variation of Ash Reduction in case of}

Tetrahydrofuran, 1, 4 Dioxane, Diethyl Ether with

\section{Particle Sizes}

Different experiments have been conducted for different sizes of coal using three solvents. Experimental results have been shown in table 6 and it has also been presented graphically as shown in figure 9. It has been evident from figure 9 that ash removal gradually increases as the particle size of coal is decreased due to the increase of surface area of coal particle. The reduction of ash content of sample is also significantly high in case of Tetrahydrofuran with respect to 1,4 Dioxane and Diethyl ether. The trends of the lines are almost linear for all three solvents. 
Table- 6: Variation of ash reduction in case of Tetrahydrofuran, 1,4 Dioxane, Diethyl ether with particle sizes

\begin{tabular}{|c|c|c|c|}
\hline $\begin{array}{c}\text { Average Particle } \\
\text { Size (mm) }\end{array}$ & \multicolumn{3}{|c|}{ Maximum Ash Removal Percentage } \\
\hline & Tetrahydrofuran & 1,4 Dioxane & Diethyl ether \\
0.126 & 23.16 & 15.26 & 12.42 \\
\hline 0.258 & 21.78 & 13.91 & 10.86 \\
\hline 0.403 & 20.45 & 11.52 & 9.76 \\
\hline
\end{tabular}

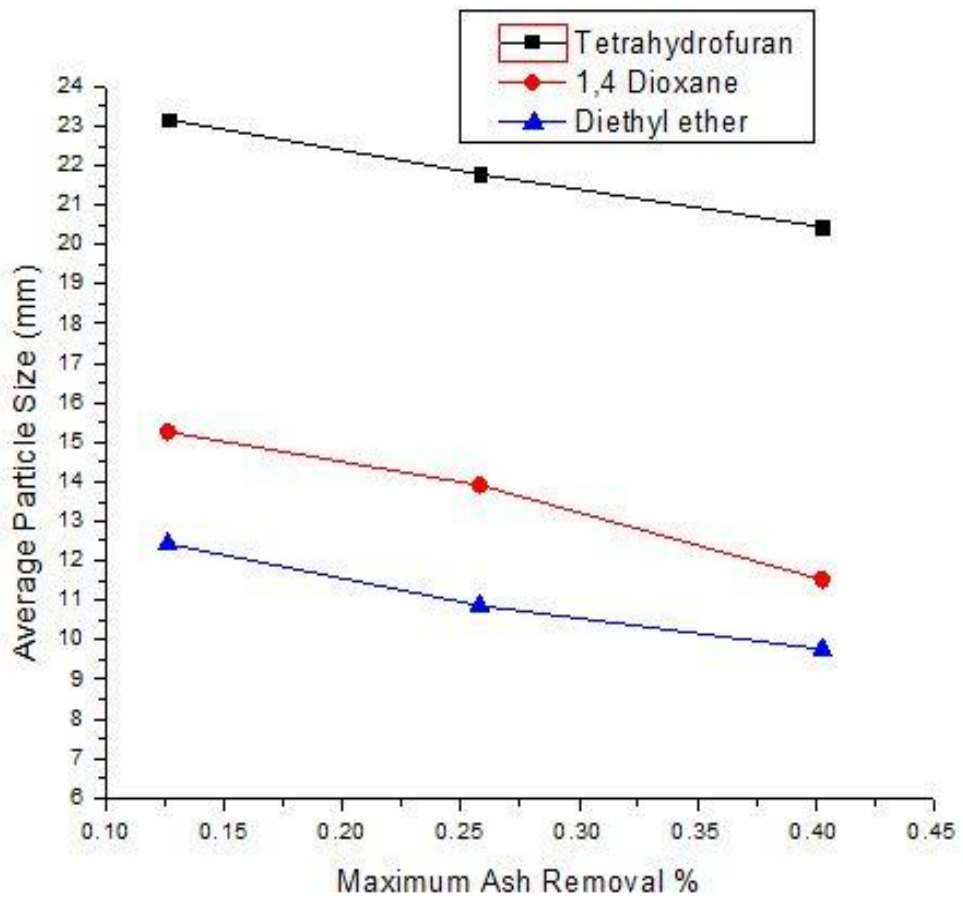

Fig- 9: Variation of ash reduction in case of Tetrahydrofuran, 1, 4 Dioxane, Diethyl ether with particle sizes

\section{CONCLUSIONS}

Removal of mineral matter of Indian coal has been studied using three solvents with different particle sizes. Experimental studies help to conclude (a) reduction of mineral matter is much more better in case of solvent Tetrahydrofuran with respect to 1,4 dioxane and diethyl ether and maximum reduction of mineral matter is $23.16 \%$. (b) The particle size of coal has a significant effect on reduction of mineral matter using solvents. More reduction of sizes of coal indicates more reduction of mineral matter within the range experiments. But extra energy is required to grind the coal sample to a finer size which hinders the process. The most favorable option based on achieving a balance between the advantages of a finer coal particle size and disadvantages from higher energy requirements. (c) The concentration of coal to solvent has remarkable effects on reduction of mineral matter. The maximum reduction of mineral matter is obtained at a concentration 1:50.

The upgraded coal using this process can be used for manufacturing of higher grade coke that may be used for the manufacturing of electrodes, anodes, graphite etc. 


\section{ACKNOWLEDGEMENTS}

I greatly thankful to chemical engineering department of Jadavpur University for allocation this valuable project to me and providing me time to time assistance for laboratory requirements I also thank my project guide Dr. Chanchal Mondal who gave me his valuable instruction for done this project very smoothly.

\section{REFERENCES}

[1]. Choudhury R., Bhaktavatsalam A.K., 1995 "Benification of Indian Coal by Chemical Technique, Energy Converse anagement", 38(2), 173-178

[2]. A.K. Mukherjee, C.N. Chatterjee and S. Ghose, Coal resources of India - Its formation, distribution and utilization, Fuel Science \& Technology, (1982) 19-34.

[3]. Bickelhaupt, R.E., "A Technique for Predicting Fly Ash Resistivity”, EPA-600/7-79-204. US EPA, Research Triangle Park, NC, 27711, August 1979, NTIS PB-80-102379le Valley, New Hampshire, USA, July 16-22, 1995

[4]. Hatt, R., "Correlating the Slagging of a Utility Boiler with Coal Characteristics" Engineering Foundation Conference, Watervil

[5]. Hyper-coal process to produce the ash-free coal Noriyuki Okuyama a,*, Nobuyuki Komatsu a, Takuo Shigehisa a, Takao Kaneko b, Shigeru Tsuruya

[6]. Hatt, R, "Washed Coal From a Utilization Perspective", World Coal, August 1997

[7]. "Impact of Coal Quality and Coal Beneficiation on Utility Boilers", 2005 Coal Preparation Directory and Handbook, (C) Copyright Coal Age and Coal Preparation Society of America, p23-33

[8]. Waugh AB, Bowling KMcG. Removal of mineral matter from bituminous coals by aqueous chemical leaching. Fuel Processing Technology 1984; 9:217-33.

[9]. R.B. Jones, C.B. McCourt, C. Morley, K. King, Fuel 64 (1985) 1460.

[10]. B.J. Arnold, D.B. Smith, Mining Eng. 10 (1994) 1144.

[11]. S.A.A. Jayaweera, J.H. Moss, M.W. Thwaites, Thermochim. Acta 152 (1989) 215.

[12]. M.V. Ko“k, E. O” zbas, O. Karacan, C. Hic syilmaz, J. Anal. Appl. Pyrolysis 45 (1998) 103.

[13]. J.P. Mathews, P.G. Hatcher, A.W. Scaroni, Fuel 76 (1997) 359.

[14]. J.M. Lytle, J.L. Daniel, G.L. Tingey, Fuel 62 (1983) 1299.

[15]. Fuel and Energy Centre, Nottingham University, Nottingham, UK The Production of Ultra Clean Coal by Chemical Demineralisation Steel, K. and Patrick, J. 2001

[16]. Shivaprasad, K.H., Nagabhushana, M.M., Venkataiah, C., 2010 "Reduction of ash content in Raw coal using acid \& alkali”, E-journal of Chemistry, 7(4):1254-1257

[17]. Hildebrand, J. H., Prausnitz, J. M. and Scott, R. L., Regular and Related Solutions, Van Nostrand - Reinhold, Princeton, New Jersey, 1970.
[17]. Hildebrand, and Scott, R. L., Solubility of NonElectrolytes, 3rd. ed., Reinhold, New York, 1950; Dover, New York, 1964

[19]. van Krevelen, D. W., "Chemical Structure and Properties of Coal XXXIII- Coal Constitution and Solvent Extraction," Fuel, (1966), , 229.

[20]. Hombach, H. P., "General Aspects of Coal Solubility," Fuel, (1980), , 465.

[21]. Gutmann, V., "Solvent Concepts," Chemtech, (1977), 7 (4), 255.

[22]. Gutmann, V..1976, "Empirical Parameters for Donor and Acceptor Properties of Solvents," Electrochimica Acta, (1976), g, 661.

[23]. Marzec A., Juzwa M., Betlej K., Sobkowiak M., 1979. Bituminous Coal Extraction in Terms of Electron-Donor andAcceptor Interactions in the Solvent/Coal System. Fuel Processing Technology, 35-44

[24]. Stiller A.H., Sears J.T., Hammack R.W., Coal Extraction Process, United States Patent

4,272,356, june 9, 1981

[25]. Dryden I.G.C., 1951. Action of Solvents on Coal at Lower Temperatures, Fuel, 30, 39-44

[26]. Roy J., Banerjee P., Singh P.N., 1976. Action of Dipolar Aprotic Solvents on Coal, Indian Journal of Technology, 14, 298-300.

[27]. Liang X., Wang Z., Zhou Z., Huang Z., Zhou J., Cen K., 2013 Up to date life cycle assessment \& comparison study of clean coal power generation technology in China, Journal of cleaner production, 39, 24-31

[28]. Song C.Schobert H.H. Fuel Process Technol $1993 ; 34: 157$

[29]. Annual Report India Energy Book, 2012, India, World Energy Council, (available at: www.wecimc.org or www.indiaenergycongress.in) World Energy Investment Outlook-2003 Insights",2006, International Energy Agency, pg 319-323 (available online at: http://www.worldenergyoutlook.org/media/weo website/20081994/weo2003.pdf)

[30]. Annual Report India Energy Book, 2012, India, World Energy Council, (available at: www.wecimc.org or www.indiaenergycongress.in) World Energy Investment Outlook-2003 Insights", 2006, International Energy Agency, pg 319-323 (available online at: http://www.worldenergyoutlook.org/media/weo website/20081994/weo2003.pdf)

[31]. The Indian coal sector: Challenges and future outlook Indian Chamber of Commerce (available at:www.pwc.com/india)

[32]. Larsen, J.W., Green, T.K., Kovac, J., "The Nature of the Macromolecular Network Structure of Bituminous Coals", Journal of Organic Chemistry, 50 (1985) 4729-4735

[33]. Crawford A. The preparation of ultra-clean coal in Germany. Trans Inst Min Eng 1951;3:204-19.

[34]. Kindig JK, Reynolds JE. Integrated coal cleaning process with mixed acid regeneration, United States Patent $1987 ; 4,695,290$ 
[35]. Lloyd R, Turner MJ. Method for the continuous chemical reduction and removal of mineral matter contained in carbon structures, Worldwide Patent 1986; 86/04917

[36]. Demineralization of a UK bituminous coal using HF and ferric ions Zhiheng Wu, Karen M. Steel*

\section{BIOGRAPHIES}

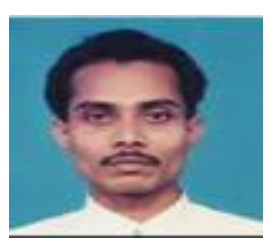

Dr. Chanchal Mondal has completed his Masters and Ph.D in Chemical Engineering from Jadavpur University, Kolkata. He is now associated professor in Jadavpur University, Kolkata in Chemical Engineering department. His teaching and research areas of Fuels and Combustion, Fluid Mechanics, Coal demineralization by chemical techniques, Biogas production by an anaerobic digestion from mixed Fruit and Vegetable waste.

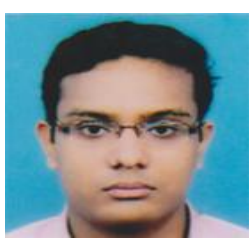

Rajat Subhra Samanta has completed his B.TECH degree from Heritage Institute of Technology, Kolkata under West Bengal University of Technology. He has completed "Biodiesel Production and Process Optimization" under the guidance of Prof.M K Das during his undergraduate course.At present, he is pursuing Masters from Jadavpur University, Kolkata. His areas of interest include chemical engineering Thermodynamics, Heat Transfer, Fluid Mechanics, Chemical Process Technology etc. His project is based on the field removal of ash from high ash content Indian Coal by using different chemical reagents. 